\title{
APPELLATE REVIEW OF PRIMARY SENTENCING DECISIONS: A CONNECTICUT CASE STUDY*
}

TrIBUNals empowered to review criminal sentences imposed by trial judges and other primary sentencing authorities ${ }^{1}$ can contribute significantly to the improved use of criminal sanctions. Review affords a second look at the sentence in light of the societal aims which such sanctions should achieve. More important, the body of decisions made by the reviewing tribunal may provide meaningful criteria for the guidance of sentencing authorities. Although in thirty-nine states and the federal courts no sentence within the statutory limits" for a proven offense may be modified by a higher court, ${ }^{3}$ eleven states now: have some system of appellate review. Of these eleven, nine vest the power to affirm or reduce sentence in their existing appellate courts.* Massachusetts :

"The Yale Law Journal wishes to express its appreciation to Chief Judge Howard W. Alcorn of the Connecticut Superior Court, who generously permitted the Law Journal to use the facilities of the Connecticut Sentence Review Division for this study; Robert C. Zampano, Esq., the executive secretary of the Review Division; members of the Connecticut bench and bar; and other observers of the criminal process for their valuable criticism. Because interviews were conducted under an assurance of anonymity, iniormation thus obtained is indicated by an asterisk $\left(^{*}\right)$ in the text. Unpublished decisions of the Sentence Review Division are eited herein as Conn. S.R.D. Unless otherwise indicated, the sentence of the trial court was affirmed.

1. There are three primary sentencing authorities active in American jurisdictions: the trial judge, the jury, or an administrative board. For a list of sentencing authorities by jurisidiction, see Tappan, Sententing ander the Model Penal Code, 23 Law \& Costcurs. PROB. 528, 532 (1958).

2. For the procedure followed by appellate courts in correcting sentences which exceed the statutory limits for the offense, see Hall, Reduction of Criminal Sententes an Appeal: I, 37 Colum. L. Rev. 521, 525-28 (1937) [hereinafter cited as Hall].

3. See 28 U.S.C. $\$ 2105$ (1958); Gore v. United States, 357 U.S. 386 (1958) : Lnited States v. Rosenberg, 195 F.2d 5\&3 (2d Cir. 1952). For the earlier federal rule, see Act of Miarch 3, 1879, ch. 176, 20 Stat. 354; United States v. Wynn, 11 Fed. 57 (C.C.E.D. Mo. 1882). Appellate review of criminal sentences in the federal courts has been pruposed in Congress, see H.R. 270, 85th Cong., 1st Sess. (1957), but the Judicial Conference of the United States declined to recommend its adoption. See Hearings Befor Sulcommittee No. 3 of the House Committee on the Judiciary, 85th Cong., 2d Sess., ser. 14, at 40 (1958) [hereinafter cited as Hearings].

The state rule is typified by Wilson v. State, 268 Ala. 86, 105 So. 2d 66 (1958). Sce, e.g., People v. Odle, $37 \mathrm{Cal} .2 \mathrm{~d}$ 52, 230 P.2d 345 (1951); People v. Losinger, 331 Xrich. 490, 50 N.W.2d 137 (1951), cert. denied, 343 U.S. 911 (1952); Hutley v. Florids, 94 So. 2d 815 (Fla. 1957). A few state courts have indicated uncertainty as to their power to review, See State v. Sorrentino, 36 Wyo. 111, 120, 253 Pac 14, 16 (1927); State v. Goodall, 221 S.C. 175, 179, 69 S.E.2d 915, 916 (1952) (dissenting opinion).

4. N.Y. Code Crñ. Proc. \$ 543-1 (appellate division), \$ 764 (county court). The New York Court of Appeals is without power to reduce sentence. Pcople v. Speiser, 277 N.Y. 342, 14 N.E.2d 380 (1938). Neb. Rev. STAT. \$29-2308 (1956), compare Barney v. State, 49 Neb. 515, 68 N.W. 636 (1896) (held unconstitutional), vith Palmer v. State, 70 Neb. 136, 97 N.W. 235 (1903) (reversing Barncy); Iowa Cone Aws. $\$ 793.18$ (1950): Artz. Rev. Stat. Ans. \& 13-1717(B) (1956) (a direct adoption of the Moder Cons Cris. 
and Connecticut ${ }^{\circ}$ have created special tribunals outside their established judicial structures and have authorized them to affirm, reduce, or increase sentences on appeal. ${ }^{7}$ This Comment will attempt to evaluate the Connecticut experience in sentence review, discussing first the general problems of sentencing ${ }^{8}$ and, second, the success of Connecticut's Sentence Review Division in dealing with these problems.

\section{The Need for Sentencing Criteria}

Despite the importance and complexity of its decision, the sentencing authority ordinarily has no standards to measure the appropriateness of its dispositive action. Judges seldom write opinions formalizing their sentencing decisions and therefore usually fail to articulate the reasons for the sentences which they impose. The absence of formalized criteria may also be the prodtict of a belief that the disposition of convicted offenders involves an intuitive process not amenable to rational analysis. ${ }^{9}$ In the opinion of one judicial commentator: "Our judgment ... is better than our reasons. And it is vain to attempt to explain the exact proportions attributable to our interest in punishment, retribution, reform, deterrence, and even vengeance."10 Nevertheless, the

Proc. $\S 459(2))$; HawaII Rev. Laws $\S 212-14$ (1955). Some state courts have inferred a power to reduce sentence, usually from a statute that allows the court to "reverse, affirm, or modify the judgment." See Hooper v. State, 7 Okla. Crim. 43, 121 Pac. 1087 (1912); State v. Ramirez, 34 Idaho 623, 203 Pac. 279 (1921); Commonwcalth v. Garramone, 307 Pa. 507, 161 Atl. 733 (1932), 108 U. PA. L. REv. 434 (1960) ; Brown v. State, 34 Ark. 232 (1879).

5. Mass. Ann. Laws ch. $278 \S 28 \mathrm{~A}-\mathrm{D}$ (1956).

6. Conn. Gen. Stat. \$§ 51-194-97 (1958), as amended, § 51-196 (Supp. 1959).

7. In addition, the Uniform Code of Military Justice provides for mandatory review of sentence by the Convening Authority, 10 U.S.C. $\$ 864$, art. 64, and the Board of Review, 10 U.S.C. $\$ 866$, art. 66 (c). United States v. Landford, 6 U.S.C.M.A. 371, 20 C.M.R. 87 (1955). The United States Court of Military Appeals is without power to modify a sentence that is within statutory limits. United States v. Keith, 1 U.S.C.M.A. 442, 4 C.M.R. 34 (1952).

Since 1907, the English Court of Criminal Appeal has been empowered to reduce, increase, or change the type of punishment imposed. Act To Establish a Court of Crimminal Appeal, 1907, 7 Edw. 7, c. 23, § 3(c); see Vanderbilt, Work of England's Courl of Criminal Appeal, 12 Wash. L. Rev. 52 (1937); The Principles of Passing Sentencis, as Sheren by Cases in the Court of Criminal Appeal (1908-22), 86 Just. P. 61, 75, 86 (1922) ; Ross, The Court of Crininal Appeal ch. 7 (1911).

8. For a substantial bibliography on sentencing, see House Comm. on the Judiciary, Federal Sentencing Procedures, 85th Cong., 2d Sess. $162-65$ (1958) [hereinafter cited as Federal Sentencing Procedures].

9. Typical responses of federal judges to a Congressional survey on sentencing problems include:

We [the judges] have the experience. It has no substitute.

No set of criteria or allegedly uniform principles . . . could possibly substitute for the day [to day] and face to face experiences of the trial judge.

The trial judge is peculiarly fitted to impose sentence in the first instance . . . . Federal Sentencing Procedures 97, 100.

10. Wyzanski, $A$ Trial Judge's Freedom and Responsibility, 65 Harv. L. Rev. 1281, .1292 (1952). 
growing criticism of present techniques of sentencing ${ }^{11}$ reveals a need to inquire further into the processes of the sentencing decision.

The sentencing decision ordinarily seeks to accomplish one or more of the multiple objectives of criminal sanctions: relabilitation of the convicted offender into a noncriminal member of society; isolation of the offender from society to prevent criminal conduct during the period of confinement ${ }^{122} d e-$ terrence of other members of the community who might have tendencies toward criminal conduct similar to those of the offender (secondary deterrence), and deterrence of the offender himself after release $;^{13}$ commmunity condemnation or the reaffirmation of societal norms for the purpose of maintaining respect for the norms themselves $;^{14}$ and retribution or the satisfaction of the community's emotional desire to punish the offender. ${ }^{16}$ To make a reasoned sentencing decision a sentencing authority must determine the priority and relationship of these objectives in each particular case. ${ }^{10}$

Often, more than one aim-indeed, perhaps all-are relevant to the appropriate sentence. All may dictate the same type of disposition-incarceration. for example. ${ }^{17}$ In order to fix the quantum of incarceration ${ }^{18}$ to be applied,

11. See, e.g., Glueck, Predictive Dezices and the Individualizalion of Juslice, 23 LAW \& Contearr. Prob. 461 (1958).

12. Mrany of the most dangerous criminals are simply "warehoused." Mforris, Sentencing Convicted Criminats, 27 AustL. L.J. 186, 189 (1953). In America's best known "warehouse," the federal penitentiary at Alcatraz, California, the average sentence of the 288 prisoners on June 30,1958 was twenty-two years and one month. U.S. BunEal of Prisons, Dep't of Justice, Federal Prisons 84 (1958) [hereinafter cited as Federal Prisoxs].

13. See Wrilians, Salasond on Jurisprudence 111 (11th ed. 1957); Ball. The Deterrence Concept in Criminology and Law, 46 J. CRns. L., C. \& P.S. 347 (1955). See generally, Andenaes, General Prevention-Illusion or Reality?, 43 J. Cris. L., C. \& P.S. 176 (1952). On the subject of probation as a primary deterrent, see Natrosal. Pi, bation \& Parole Ass'd, Guides for Sentencing 12-17 (1957) [hercinafter cited as Gutdes for Sentencing].

14. See, e.g., Hart, The Aims of the Criminal Law, 23 LAw \& Coxtesrp. Prur. 401, 404-06 (1958).

15. See, e.g., Mead, The Psychology of Punitize Jistice, 23 Axs. J. Sutrowniy 577 (19i8). Commurity condemnation may be distinguished from retribution in that the former is reprobative while the latter is vindicative. See Cohen, Moral Aspects of the criminal Law, 49 Y ALE L.I. 9S7, 1009-12, 1017 (1940).

16. "A penal code that reflected only a single principle would be a very bad one... The problem . . . is one of the priority and relationship of purposes as well as of their legitimacy-of multivalued rather than of singlevalued thinking." Hart, supra note 14 , at 401 .

17. Sentencing authorities normally can choose between a suspended sentencu, juro. bation, a fine, incarceration, or a combination of these. See Guides For Sextevc1:a 12-24. If the sentence is to be incarceration, the sentencing authority may have a choice of institutions to which the offender can be committed. E.g., CoNs. Ges. STAт. $\$ \S 17-402-0$, (school for boys under sixteen), \$\$ 17-369-78 (school for girls under sixteen), \$\$ 17-350- 6 \$ (State Farm for Women), $\$ \$ 17-382-401$ (Reformatory for men, sixteen to twenty-five), $\S \S 18-23$ (State Prison for Women), §§ 18-1-22 (State Prison for men) (1958).

18. There are two basic forms of incarcerative sentences: (1) the definite senteric in which the sentencing authority sets the maximum sentence as a fixed term of years, aud 
however, the sentencing authority must consider the different policies underlying each aim and determine its relative significance in the particular case. Consider the case of three youthful first-offenders convicted of robbery. No violence was used and the stolen money was recovered. Because of the widespread incidence of juvenile offenses, the need to deter athers similarly inclined might suggest a substantial period of incarceration. Yet, in the light of the age of the offenders, the absence of violence, and the recovery of the stolen money, community condemnation and retribution might be satisfied by confinement for a lesser period. And, considering the offenders' youth and brief criminal careers, rehabilitation might be effected by a relatively bricf incarceration. The problem of choice would not be difficult if these different aims could be administered simultaneously without interfering with each other. But the rehabilitation of the offender may be impeded if the duration of incarceration is prolonged beyond the time necessary to prepare him to return to society. ${ }^{19}$ The duration of imprisonment prescribed will therefore depend on which of these aims is considered most important.

In some cases, the sentencing authority's evaluation of these competing objectives will be relevant not only to the quantum of punishment but also to the type of sanction imposed. Suppose a respected leader of the community, while driving under the influence of alcohol, hits and kills a pedestrian. If the sentencing authority emphasizes rehabilitation, it might order probation. The shock of having killed another combined with the continuing supervision afforded by probation may be sufficient to ensure that the defendant will not offend again. Community condemnation, were this the dominant aim, might be satisfied by the stigma of arrest, trial, and attendant publicity, and a sus-

the earliest possible release date is a fraction of that period or a specific number of ycurs determined by the parole eligibility statute; $(2)$ the indeterminate sentence in which the sentencing authority sets both the minimum and the maximum term of incarceration, atril the earliest possible release date is at the expiration of the minimum sentence or some fraction thereof as determined by the parole eligibility statute. These definitions have substantial expansions and variations between jurisdictions. Tappan, Sentencing Under the Modd Penal Code, 23 Law \& Contemp. Prob. 528 (1958); see 50 Hanv. L. Rev. 677 (1937); 10 W. REs. L. Rev. 574 (1959). Connecticut has an indeterminate sentencing system in which the trial judge sets a minimum and a maximum sentence within the statutory maximum for the offense. Conn. Gen. Stat. § 54-121 (1958). For some crimes, the discretion of the judge (and the appellate tribunal) are limited by mandatory sentences imposed by statute. See, e.g., Conn. Gen. STAT. $\$ 54-121$ (habitual criminal, 30 yr. maximum), §§ 53-10-11 (first and second degree murder) (1958), \& 19-265 (uarcotics offenders) (Supp. 1959).

19. "Much bitterness is engendered in many prisoners who have otherwise admirably responded to rehabilitation programs by the knowledge that they must be incarcerated for a purely arbitrary period ...." Letter from Deputy Att'y Gen. Lawrence E. Wallsh to Hon. James O. Eastland, July 25, 1958, in S. REP. No. 2013, 85th Cong., 2nd Sess. (1958), reprinted in U.S. Code Cong. \& Ad. News 3891, 3904-05 (1958). See also, id. at 3893. See generally, Donnelly, The Connecticut Board of Parole, 32 Conn. B.J. 26, 33 (1958). 
pended sentence. ${ }^{20}$ On the other hand, retribution for this criminally negligent homicide might call for a substantial fine and a period of incarceration. And, finally, the deterrence of potential offenders might suggest a prolonged period of imprisonment since drunken driving is such a common practice that stibstantial sanctions are necessary to impress upon the community the dangers involved in this type of conduct. Thus, to determine the appropriate type and degree of sanction to be applied, the sentencing authority must decide which aim is primarily to be implemented and the relative weight to be assigned to secondary aims. ${ }^{21}$

The sentencing authority must also consider the impact of its determination upon the operation of other agencies responsible for the administration of the criminal law. ${ }^{22}$ For example, the successful performance of the prosecutor's function depends in part upon the disposition of many cases by means of a plea of guilty; expensive and time consuming jury trials are avoided, and victims and witnesses are relieved from the ordeal of testifying in court. $23 \%$ A judge who, pursuant to prosecutor recommendation, is willing to make sentencing concessions can assist in obtaining guilty pleas. But a sentence which acconmodates the prosecutor may inhibit implementation of the dominant criminal law aim in a given case. ${ }^{24}$ Consider the case of the professional criminal. He is probably cognizant of the potentialities of plea bargaining and realizes that the state would prefer to avoid the delay and expense of a trial. Realizing that he stands in danger of receiving a harsh sentence on the basis of his prior record, he may offer a plea of guilty in exchange for a sentencing concession. Since isolation of the offender and deterrence of others may call for a severe sentence when professional criminals are involved, the sentencing authority

20. Gumes for Sentencing 23-24. For a dramatic description of the stigma attached to conviction, see Gardner, Bailey v. Richardson and the Constitution of the linted States, 33 B.U.L. Rev. 176, 193 (1953). See also Goldstein, Police Discrction nol T" Invoke the Crintinal Process: Low Visibility Decisions in the Administration of Justice, 69 YALE L.J. 543, 590-92 (1960).

21. The classic statement of this problem is that in Commonwealth v. Ritter, $13 \mathrm{~Pa}$. D. \& C. 285 (C.P. 1930) (Stern, J.). For other "hypothetical cases" and the sulutiun: of a federal judge, see Yankwich, Individualization of Punishnent in the Federal Courts, 20 F.R.D. 385, 391-92 (1958).

22. The police, the prosecutor, the grand jury, the judge, the petit jury, and the agencies of probation, prison administration, parole, and pardon all have interrelated responsibilities for the enforcement of the criminal law. For a graphic representation of these decision-makers, see Goldstein, supra note 20, at 563. See generally Ohlin \& Remington, Sentencing Structure: Its Effect upon Systems for the Administration of Crimiseal Iustice, 23 LAw \& ContEarp. ProB. 495, 496 (1958).

23. See Newman, Pleading Guilty for Considerations: A Study of Bargain Iustice. 46 J. CRMr. L., C. \& P.S. 780 (1956); Comment, 66 Y ALE L.J. 204 (1956); Hcarings 51-52.

24. "Such reasons [a plea of guilty] for mitigating sentence are predicated upon practical administrative considerations and do not reflect the belief that a defendant who pleads guilty is a better prospect for reformation." Comment, 66 YALE L.J. 204, 219 \& n.77 (1956). Consider the "repentance" rationale for mitigating sentence in exchange for a plea of guilty. Id. at 209-11. 
cannot accommodate the prosecutor unless he relegates these aims to a secondary position. The sentencing authority's decision will also affect the role of decision-makers who operate in the post-sentencing phases of the criminal process. The provision for a parole board reflects a policy that the precise duration of incarceration should not be fixed at trial, but should be determined by authorities at a later stage who have an opportunity to view and evaluate the offender's conduct and progress toward rehabilitation while in prison. Moreover, it represents a judgment that gradual return to the community under continuingr supervision may better prepare the offender to assume societal responsibilities. ${ }^{25}$ If the spread between the maximum and minimum sentence is natrrow, however, the opportunity for early parole is extinguished and the parole authority is deprived of the opportunity to exercise the discretionary function assigned to it. ${ }^{26}$

In order properly to assess the relative importance of all these considerations, the sentencing authority must decide what information about the offender and his offense is relevant to the sentencing decision. In those states which require preparation of presentence reports, detailed information will be collected and made available to the sentencing authority. ${ }^{27}$ This composite of information will not, however, obviate the need for selective evaluation. What, for example, is the significance to the aims of sentencing in any given case of such personal factors as age, sex, family status, and employment record? And how should the weight to be assigned to such factors vary according to the nature of the crime committed?

The present practice of giving wide discretion to the sentencing authority. coupled with the lack of criteria to assist him in correlating information about the offender and the offense with the aims of sentencing, contribute to disparity in the type or degree of sanction applied to similar offenders who have

25. These policies were the rationale behind the 1958 federal indeterminate sentence act. Federal Prisons 44. The act permits the trial judge to make the offender eligible for parole at any time or to set a minimum parole eligibility date earlier than the former date of one-third of the sentence. 18 U.S.C. $\S 4208$ (1958). However, the act has been sparingly used (124 times as of June 11, 1959). Devitt, Improvements in Fcderal Scnlcuciny Procedures, 24 F.R.D. 147, 153 (1959).

On the other hand, Professor Cohen warns that "a man's conduct in prison is not always the best indication of what he will do when released. And in point of fact prison officials can be and have been influenced by political and social pressure." Cohen supra note 15 , at 1022 .

26. Connecticut refuses its prisoners eligibility for parole until the minimum term has been served. Conn. GEN. STAT. \$ 54-125 (1958). This minimum term imposed by the trial judge is modified by the Connecticut "good time" statute. Conn. Gen. Star. \& 18-7 (Supp. 1959).

For other avemues of influence see e.g., State v. Tardiff, Conn. S.R.D., Aug. 21, 19:8 (court urged that fourteen to fifteen year sentence not be reduced by parole or pardon).

27. For discussion of the contents and form of presentence reports, see Guines ron Sentencing 33-47, 67-94. See also Moder Penal Code $\$ \$ 7.01-.04$ (Tent. Draft No. 2, 1954). 
committed similar offenses. ${ }^{28}$ Disparity without a rational basis not only offends principles of justice, but may have an inhibiting effect on the treatment phase of criminal law administration as well. Prisoner morale bears a vital relationship to prisoner response to the rehabilitative process and may be adversely affected if the offender believes that his sentence is the product of the prejudices or idiosynicracies of a particular judge. In the opinion of one parole official: "All prisoners have a certain grudge against the sentencing judge, but the hardest ones to work with are those who, after asking around and comparing, decide that their sentences represent a particular judge's harslt treatment." 29 Recognition of the problems created by disparate sentences loes not, however, compel the conclusion that all offenders who commit the same offense ought to receive the same sentence-the theory of "uniform sentencing." There may be differentiating personal and social factors which require "individualization"-different sentences for offenders who have engaged in the same antisocial conduct. ${ }^{30}$ But if a system of individualization is to satisfy objections against disparity, the disparity inherent in individualization must result from the articulated application of uniform criteria designed to effectuate agreed-upon goals.

28. Arguments about disparity are typified by Judge Goodman's statement that "I have never found a pigeon-hole into which I could put any two cases, let alone any two offenders," Goodman, In Defense of Fcderal Judicial Sentencing, 46 CaLIr. L. Rai. 497. 498 (1958), and the effort of Bureau of Prisons Director Bennett to do that job of nigconholing by comparing cases, Hearings 57-66.

Disparity in type of disposition is illustrated by the use of probation in the ietleral courts in fiscal 1958-25.3\% of the 324 federal offenders in the Eastern District of Louisiana, 54.2\% of the 190 offenders in the Western District of Louisiana. Feuenul. Parsuss 114. The percentage of offenders probationed varied from $69 \%$ in Vermont to $19: 8$ in the Western District of Tennessee. Hearings 45.

Disparity in degree of incarcerative sanctions is suggested by comparison of punishnemt for the same offense in different federal districts-in 1957 the average sentence ior liquor law violations was approximately 3.75 years in the Northern District of Indiana, 10 months in the Eastern District of Pennsylvania. Hearings 48. See generally, id. at 45-69. Disparity may exist between judges in a single jurisdiction. See GAuder, Iswivivu is DIfferences in the Sentenctng Tendencies of Judges (Arch. Psychol. Series Nu. 23u, 1938) (a study of six judges in one New Jersey county during a nine-year periud).

A substantial bibliography is collected in InstrTUTE of JubicLal Adsrisistustios, Disparity in Sentencting of Convicted Defendants (1954).

29. Statement of State Parole Officer, quoted in Consecticur Goversoz's Prusu:: Study Committee, First Interiar Report 1 (1956) [hereinafter cited as Prusos Stcur REPORT] ; accord; Hearings 52 (Director of the U.S. Bureau of Prisons, James V. Benneit). See also, Ashe, $A$ Warden's I'iew on Inequality of Sentences, 5 Fed. Pror. No. 1, p. 26 (1941) ; MeGuire \& Holtzoff, The Problem of Sentences in the Criminal Lati, + lisu. ProB. No. 4, p. 20 (1940).

30. Definitions of individualization are numerous. See, e.g., Glueck, Predictize $D_{i-}$ vices and the Individualization of Justice, 23 LAW \& Contearr. Pros. 461 (1958); Sallielles. The Individualization of Punishment 8-10 (Jastrow tr., 4 Mfodern Criminal Science Series) (1911); Cohen, supra note 15, at 1019. 


\section{The Connecticut Sentence Review Division \\ Origin, Structure, and Initial Performance}

Connecticut's introduction of appellate review of criminal sentences represents an attempt to solve some of the problems inherent in the sentencing process. In 1956, the Governor of Connecticut appointed a special committee to ascertain the causes of unrest among the prison population. ${ }^{31}$ Among other factors, the committee noted the relationship between prisoner discontent and alleged "inequality of sentences" imposed by different judges for the same crime. ${ }^{32}$ Although the committee opposed the principle of uniform sentencing and endorsed instead the principle of individualization, it emphasized that "as long as a prisoner feels that he has been denied review of a sentence which he deems unfair or unduly harsh he remains a source of trouble in the prison system." ${ }^{33}$ The committee therefore recommended establishment of a system of expeditious and effective sentence review, enabling the offender to "enter the crucial first stage of prison life with at least one less grievance and with a feeling that his sentence does not represent the bias and prejudice of a single judge." 34 Additionally, the committee hoped that the power of the appellate tribunal to demand from the trial judge an explanation of his reasons for a particular sentence, its power to modify sentences, and its obligation to publish the reasons for the disposition of every appeal, would encourage trial judges to rationalize the sentencing function and to justify the sentences they impose or uphold. ${ }^{35}$ More important was the belief that the opinions of the reviewing

31. In response to prisoner "grievances" presented during a riot, Governor Ribicoff appointed a Prison Study Committee composed of Patrick B. O'Sullivan, retired justice of the Supreme Court of Errors of Connecticut; Rev. John Bonn of Fairfield University; Warren Mottram, Connecticut business man; Rosemary Park, President of Connecticut College for Women at New London; and Eugene V. Rostow, dean of the Yalc Law School. Hartford Courant, July 31, 1956, p. 1, col. 8. The committec consulted with a number of nationally known figures in the field of penology. Hartford Courant, Aug. 3 , 1956, p. 1, cols. $1-8$.

32. Prison Study Report 1. Later reports of the committee dealt with revampiny the State's correotional system.

33. Id. at 1-2.

34. Id. at 9-10; see note 28 supra.

35. Prison Study Report 10.

Speaking of the English Court of Criminal Appeal, the Lord Chief Justice of England noted :

It is not so much that a conviction is sometimes quashed or a sentence is sometimes reconsidered. What matters, and matters profoundly, is that everybody cngaged in administering the criminal law upon whatever rung of the ladder he may be, throughout the whole hierarchy, is well aware that a Court of Criminal Appecal is in existence. The consequences of the diffused and abiding knowledge are quitc incalculable.

Address of the Lord Chief Justice of England, Rt. Hon. Baron Hewart of Bury to the Twelfth Annal Meeting of the Canadian Bar Association, 5 CAN. B. Rev. 564, 572 (1927). See also Wyzanski, supra note 10 , at $1292-93$. 
authority would develop a uniform set of principles for sentencing and ensure the application of these principles throughout the state..$^{30}$

To establish a review system which would best achieve these goals, the Prison Study Committee examined procedures used in other jurisdictions which permit reduction of sentences set within statutory limits. Nine states employ traditional channels of review, joining sentence appeal with appeals against conviction. $^{37}$ The reviewing court is empowered only to affirm or reduce the sentence set below. ${ }^{38}$ As in appeals against conviction, the offender himself does not appear before the reviewing court. Theoretically, such a procedure might achieve adequate sentence review. In practice, it does not. First, the inordinate time, money, and effort consumed in prosecuting an appeal through normal channels limits the opportunity for review. ${ }^{30}$ Second, a review conducted in the absence of the offender deprives the reviewing court of whatever value demeanor evidence may have in the sentencing process. ${ }^{40}$ Moreover, if one purpose of review is to facilitate the rehabilitative process by convincing the offender that he has had another opportunity for full and fair consideration of his sentence, his appearance before the review tribunal would seem essential."11 Third, the power to alter sentence in conjunction with the power to hear appeals from conviction is a temptation to some appellate courts to "correct" nonreversible trial errors by reducing the sentence."2 If criminal sanctions are to be used to achieve the various aims of the criminal law, such errors should

36. Letter From Chairman O'Sullivan to Governor Ribicoff, Dec. 3, 1956 (accompanying PRISON STUDY REPORT).

37. See, e.g., Heartsill v. State, 341 P.2d 625 (Okla. Crim. 1959); Commonwealth v. Green, $396 \mathrm{~Pa} .137,151$ A.2d 241 (1959). Occasionally there are appeals against sentence alone. Guedea v. State, 162 Neb. 650, 77 N.W.2d 166 (1956); Parsons v. State, 156 Neb. 847, 58 N.W.2d 182 (1953).

38. See note 4 supra.

39. Availability of appeals in forna panteris may alleviate the financial burden in some states. See Griffin v. Illinois, 351 U.S. 12 (1955).

40. The value of demeanor evidence in the sentencing area remains a matter of dispute. Federal judges who oppose appellate review state: "[T]he judge... has had an opportunity to observe the defendant personally, in many instances to see and hear him testify, to determine his attitude toward the courts and toward society and to analyze his character, his personality, his background ...." Federal Sentencing Procedures 118 . See also $i \bar{d}$. at $116(2)-(3), 119$ (11)-(12). On the other hand: "If ever there is a situation in which it is impossible to make a balanced assessment of the personality of the person undergoing it, it is the 'day in court' .... One does not gain a balanced insight of a man by observing him only in times of one of the greatest stresses to which he can be subjected." Morris, Sentencing Convicted Crimials, 27 Austr. L.J. 186, 193-94 (1953).

41. One Connecticut observer suggests that a review hearing offers the offender a chance to "blow off steam."

42. The Oklahoma Court of Criminal Appeals frequently "corrects" errors below: by reducing sentence. See e.g., Glassgow v. State, SS Okla. Crim. 279, 202 P.2d 999 (1949) ("give the defendant the benefit of the doubt" on the issue of prejudicial error) ; IfeKinnon v. State, 299 P.2d 535 (Okla. Crim. 1956) (objectionable questions by prosecutor varmant reduction); Johnson v. State, 305 P.2d 1051 (Okla Crim. 1957) (erroneous admission of hearsay evidence corrected). Perhaps the number of such "corrections" is related to 
have no relation to the determination of the most appropriate sentence. ${ }^{40}$ Fourth, the opinions of these tribunals do not disclose any effort to articulate and establish criteria for sentencing. Many opinions consist simply of a discussion of the points of law raised on appeal, the mention of a few personal factors concerning the offender, and a short statement that "uncler all the circumstances" the sentence below is affirmed or reduced. 44 Fifth, when the original sentence imposed is too short to achieve the relevant criminal law goals, the lack of power to increase sentences not only prevents satisfactory disposition of the individual offender, but also inhibits the development of a complete and consistent body of sentencing principles..$^{45}$

For these reasons, Connecticut rejected the idea of assigning the sentencereview function to its Supreme Court of Errors. ${ }^{46}$ Instead, it adopted a modified form of the review system used in Massachusetts ${ }^{47}$ and established a Review Division of the Superior Court. ${ }^{48}$ By statute, the Connecticut Sentence Review Division is composed of three Superior Court trial judges and is empowered to review sentences which direct incarceration for one year or more in the state prison, ${ }^{49}$ and to substitute any sentence that the trial judge could have imposed, including an increased term.50 Upon imposition of sentencc,

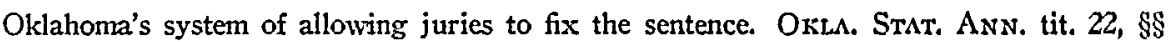
926-27 (1958) ; see State v. Yediares, Conn. S.R.D., Oct. 17, 1958 (erroneous presentation of the offender's prior record to the sentencing judge corrected by reduction).

43. Some observers, however, feel that the value of these reductions lies in the fact that they prevent unnecessary new trials. 18 NEB. L. REv. 300, 303 (1939). See Hall, at 771-75, 783.

44. People v. Downs, 172 N.Y.S.2d 377, 5 A.D.2d 935 (1958); Prison Stupy Rapokt 7-8; see, e.g., Rahal v. State, 320 P.2d 716, 719 (Okla. Crim. 1958) (sentence reduced in "interests of justice and fair play").

45. We have all observed instances of excessive sentences but, just as frequently, we have noted instances of commitments far too short to enable institutional authorities to educate and train the individual to take his place in the community as a law abiding self-respecting citizen.

Chief Justice Warren, Introduction to Glueck \& Guuteck, Predicting Detinguencr xix (1959). (Emphasis added.) See also S. Rep. No. 2013, 85th Cong., 2d Sess. (1958), reprinted in U.S. Code Cong. \& Ad. News 3891, 3893 (1958).

46. Prison Study Report 7-8. The Court has consistently held that it does not inherently possess such power. State v. La Porta, 140 Conn. 610, 102 A.2d 885 (1954); State v. Van Allen, 140 Conn. 39, 97 A.2d 890 (1953).

47. Mass. Ann. LAws ch. 278, $§$ 28A-D (1956).

48. Connnecticut's Superior Court has exclusive jurisdiction over all crimes punishable by a sentence greater than a $\$ 500$ fine and/or one year imprisonment. ConN. Gin. STA'r. $\S \S 54-7,54-17$ (1958).

49. Conn. Gen. Stat. \$ 51-195 (1958). The legislation proposed by the Prison Study Committee would have made appealable any sentence by the Superior Court "to a term of imprisonment," PRISON STUDY REPORT 12, presumably including reformatory or jail sentences. As passed by the legislature, appeal was limited to those sentenced to the State Prison for Men or the State Prison for Women.

50. The Prison Study Committee's draft legislation contained a provision allowing an increase of sentence on appeal. Prison StUdy Report 13. The act initially passed by the 
the clerk of the sentencing court must give the offender written notice of his right to appeal to the Review Division within thirty days, and notice of the possibility that his sentence will be increased on appeal. ${ }^{51}$ While the Division has construed the statute to prevent it from considering evidence which was not before the trial judge, ${ }^{52}$ such as post-sentence rehabilitation and "cooperation," the statute allows the Division to require the production of presentence reports and "any other records, documents, or exhibits connected with such review proceedings." 53 The trial judge may submit a statement of his reasons for a particular sentence to the Division and the Division may require the submission of such a statement. ${ }^{54}$ The most important change from the Massachusetts procedure is the requirement that the Division hand down a written opinion stating the reasons for the disposition of each appeal.55

In practice, the Division's panel of judges has been rotated among the judges of the Superior Court. ${ }^{56 *}$ Every appellant is permitted to appear before the Division and is allowed representation by counsel.57 The State's Attorney from the county in which the offender was prosecuted appears at the hearing for the state.* In lieu of requiring the trial judge to prepare a statement of reasons for a particular sentence, the Division sends for the transcript of the arguments of the State's Attorney and the defense counsel together with the comments of the trial judge in open court on sentencing day.s Thus the Division has before it the presentence report, the transcript of sentencing day proceedings, and other documents, such as psychiatric studies, which were before the primary sentencing authority.* In addition, the Secretary of the Division prepares a synopsis of these documents for each judge of the Divi-

legislature did not permit increases in sentence. Conn. Pub. Laws, Jan. Sess. 1957, P.A. 436, S. 2. Some observers protested that the lack of this power would cause the Sentence Review Division to be swamped with frivolous appeals. Hartford Courant, Oct. 2, 1957, p. 2, col. 1-3. The act was then amended to give the Division the power to increase sentence. Conn. Pub. Laws, Sept. Spec. Sess. 1957, P.A. 14, § 2, Coss. Gex. Stat. § 51-196 (1958).

51. Conn. Gen. Stat. § 51-195 (1958). The Prison Study Committee felt that a thirty day appeal period would be an improvement over the three-day period in use in Massachusetts by allowing the offender an opporunity to recover from the shock of conviction. Prison Study Repori 10. The notice provision of the statute, a modification of the Massachusetts procedure, is an effort on the part of the comnittee to avoid any double jeopardy claim. Ibid. For further discussion of this problem, see id., appendix.

52. Connecticut v. Ferrini, Conn. S.R.D., Oct. 20, 1959; State v. Harris, 21 Conn. Supp. 448, 159 A.2d 188 (Rev. Div. Super. Ct. 1958).

53. Conn. Gen. Stat. § 51-196 (1958).

54. Ibid.

55. Conn. Gen. Stat. § 51-196 (1958).

56. In addition, when the Division panel reviews a sentence imposed by one of its members, that member is disqualified and replaced. CoNs. GEN. St八t. § 51-194 (1958).

57. See Review Division of Superior Court, Rules and Regulations, \& 1. The draft legislation proposed by the Prison Study Committee followed the Mfassachuselts statute in making a hearing mandatory only in cases of increases. PrIson Study Report 11. None of the revisions of the Review Division Statute have contained any provision for hearing.

58. Review Division of Superior Court, Rules and Regulations \& 2. 
sion. ${ }^{59}$ Normally the Division will hand down its written opinion within a month after the hearing.* The Division sits as its business requires, meeting approximately one day every two months to dispose of less than twenty-five cases. To date, the Division has heard two-hundred-fifty-six appeals, reducing fifteen sentences and increasing seven. ${ }^{60}$ In only one case was the type of punishment imposed by the trial judge changed. ${ }^{01}$

The relatively small number of sentence modifications ${ }^{\mathbf{6} 2}$ has been explained by some members of the Division by reference to the class of criminals who appeal their sentences.* Since the Division has the power to increase as well as decrease sentences, creating a risk for the appellant, the majority of appeals have come from those prisoners who have the least to lose, those sentenced in the upper range of penalties for their offense. ${ }^{63}$ Therefore, it is argued, the bulk of appeals come from the most dangerous class of offenders in the prison." It is implied that the Division might feel justified in modifying more sentences if it met the less serious offenders. This line of reasoning indicates a basic misconception of the philosophy which should underlie effective sentence review. The conclusion that those serving high sentences are the most dangerous

59. These synopses are on file in the Review Division Office, 121 Elm Strcet, New Haven, Conn. [In subsequent citations, these documents will be cited: Synopsis].

60. Tabulation taken from files of Sentence Review Division, July 5, 1960.

61. State v. Howarth, 21 Conn. Supp. 431, 158 A.2d 865 (Rev. Div. Super. Ct. 1958).

The Massachusetts panel changes the type of sentence frequently. E.g., between Junc 1,1954 , and June $30,1955,24$ sentences to the state prison were changed to 22 sentences to the Reformatory and 2 sentences to the House of Correction. This represented more than one-third of the 66 sentences (involving 33 individuals) molified by the Appellate Division during that period. 31 Report of the Judicial Council of Massachusetts, Mass. Pub. Doc. No. 144, at 81-85 (1955).

62. Between 1943 and 1956, the Appellate Division of the Massachusetts Superior Court acted upon more than 1200 appeals, decreasing approximately 350 sentences while increasing less than twenty. 23-32 Report of the Judicial Council of Massachusetts, MAss. Pub. Doc. No. 144 (1946-1956). Several possible explanations might be suggested for this wide discrepancy in sentence review results: (1) the absence of a requirement for a written opinion may permit the Massachusetts panel a greater leeway in reflecting its personal attitudes toward offenders and offenses than would be the case if it were forced to formalize its decisions. This theory does not, however, explain the preponderance of decreases in sentence. (2) Statutory sentencing policy in Massachusetts may be more severe than in Connecticut. Compare the following ma.ximum sentences:

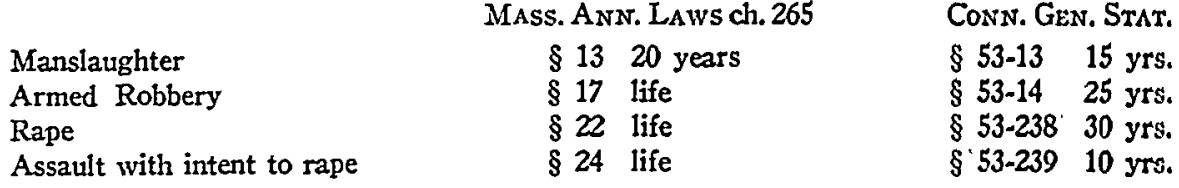

3) A large segment of the Massachusetts modifications are actions making consecutive sentences run concurrently. In Connecticut, only the maximum terms for separate offenses can run consecutively; most minimum terms run concurrently. Cons. GEN. STAT. \& 54-121 (1958). But see Conn. Gen. Stat. \$ 53-163 (1958).

63. The Division noted this fact in State v. Young, 21 Conn. Supp. 415, 158 A.2d 595 (Rev. Div. Super. Ct. 1958). 
offenders in the prison assumes the answer of the very question which review is intended to raise-whether the sentencing judge was correct in his classifcation of the offender. Moreover, there would seem to be no basis for assuming that sentences in the higher ranges are either more or less correct than sentences in a lower range. ${ }^{64}$ The Division's attitude toward higher sentences may stem from excessive deference to the sentencing judge. Admittedly, the judge who has seen the offender during trial may be better informed about the defendant. ${ }^{65}$ But this advantage is not present in the far greater number of cases in which the defendant has pleaded guilty, without being tried. ${ }^{\text {cs }}$ In these cases the Review Division of three judges will have all of the information which was before the sentencing judge, and probably a better opportunity to gather demeanor evidence. For this reason, the Review Division should approach each sentence with no assumptions based upon the length of the sentence imposed below.

The infrequency of significant sentence modifications and the de facto limitation upon the class of offenders who elect to appeal may detract from the Division's usefulness as a device for alleviating alleged prisoner discontent with "unfair" sentences. Prisoners regard the infrequency of modification as evidence that the Division is a sham, ${ }^{67}$ thus removing any legitimizing influence which review might afford. Even if there had been more sentence changes made, however, the possibility of increased sentences prevents the potential benefits of review from reaching a substantial number of offenders with low sentences who may nevertheless believe their sentences to be unfair. Arguably then, to the extent that alleviation of prisoner unrest is a goal of sentence review, no prisoner ought to be discouraged by the threat of an increased sentence from pursuing an appeal to the Review Division. Removing both these impediments to prisoner acceptance of the review board, sentence review might still fail to reduce prisoner discontent. One observer has suggested that it is probably impossible to impress upon the prisoner mentality the concept of individualized sentences tailored to effectuate sentencing goals, if individualization results in a sentence greater than that received by others

64. The "class" of offenders with higher sentences will not include those convicted of first or second degree murder, whose mandatory sentence, CoNN. GEN. STAT. \$ 53-10, 11 (1958) precludes their appeal, ConN. GeN. Stat. § 51-196 (Supp. 1959).

65. For examples of deference based upon the trial judge's access to demeanor evidence, see State v. Ferraro, Conn. S.R.D., Aug. 21, 1958; State v. Higgs, Conn. S.R.D., Oct. 2, 1958; State v. Wade, Comn. S.R.D., Sept. 25, 1958. For arguments pro and con on value of demeanor evidence, see note 40 supra.

66. The distinction seems to have been overlooked in State v. Hackley, 21 Conn. Supp. 412, 158 A.2d 859 (Rev. Dev. Super. Ct 1958) ; State v. Eno, Conn. S.R.D., June 30, 1958; State v. Tardiff, Conn. S.R.D., Aug. 21, 1958. In these cases the Division had before it the same amount of information available to the trial judge. See text at notes 58-59 supra.

67. Letter From Inmate Leroy Nash to Connecticut Sentence Review Division, Apr. 18, 1958 on file in Sentence Review Division Office, 121 Elm Street, New Haven, Conn.: "Your last seventeen decisions (today is July 18) caused a loud wail of "I told you! The dirty double__. And the rehabilitation program took an abrupt nose dive." 
who have committed similar offenses.* The prisoner tends to make a shallow comparison based only on the type of offense and possibly on the number of prior convictions. ${ }^{68}$ Therefore, alleviation of prisoner unrest may not be $a$ realistic goal of sentence review under any circumstances.

But these shortcomings do not compel the conclusion that the concept of appellate review of sentencing ought to be abandoned. If the Review Division can create and articulate uniform sentencing principles, it can make a major contribution toward establishing an integrated and rationalized use of criminal sanctions by all of the decision-makers in this area. Trial judges, for example, would then be impelled not only to impose reasonable sentences but also to justify affirmatively their decisions in terms which they feel will accord with the Division's prior articulations of relevant sentencing aims. Similarly, the State's Attorneys, whose recommendations may carry significant weight with the trial judge, would be able to relate the factors underlying their recommendations to sentencing goals which they have been able to abstract from the Division's opinions. Defense attorneys cotld also draw on these principles in their presentence argument and in plea bargaining negotiations. And after the minimum term of incarceration has been served, the Board of Parole would be able to compare the aims it considers relevant in deciding whether to parole the offender with those considered dominant at the time of his sentencing.

\section{The Policy-Making Function}

To improve sentencing decisions, the Review Division must write opinions which clearly describe the relationship between the factors involved in it specific case and the aim or aims of the criminal law that should be emphasized in that case. With relatively few exceptions, the opinions of the Connecticut panel have not satisfied this requirement. Some opinions give relatively clear directions to trial judges. Others, if supplemented by a tentative process of extrapolating principles from the facts apparently considered significant in the opinion, may furnish limited guidance in future cases. But in a substantial number, it is extremely difficult if not impossible to deduce what aim or aims of the criminal law are being emphasized and, a fortiori, to abstract any sentencing principles. Examination and comparison of individual Review Division opinions will illustrate the kind of opinion which meets the demands of effective review, as well as pointing out some of the inadequacies of the present system.

One opinion in which the Division clearly enunciates sentencing objectives is the case of an eighteen-year-old who pleaded guilty to one count of rape and three counts of assault with intent to rape. ${ }^{60} \mathrm{He}$ was sentenced to five to

68. State v. Young, 21 Conn. Supp. 415, 158 A.2d 594 (Rev. Div. Super. Ct. 1958). The Prison Study Committee's pilot study was apparently based only upon type of crime and number of prior offenses. Prison Study RePort 3-4

69. State v. Doak, Conn. S.R.D., Oct. 7, 1958. 
ten years in the State Prison. ${ }^{70}$ On appeal from this sentence, the Review Division weighed the following factors: the defendant was eighteen years old; all four of the offenses involved violence, two at knife-point; ${ }^{71}$ the woman actually raped was seven months pregnant $;^{72}$ the defendant had a prior criminal record ${ }^{73}$ -convictions for breaking and entering and use of a motor vehicle without the owner's permission; a psychiatric examination disclosed that the defendant was of below-average intelligence; his home situation was "unfortunate"; and the original sentence imposed was based on the recommendation of the State's Attorney. ${ }^{74}$ In these circumstances the Review Division apparently felt that although community condemnation would not require an especially severe sanction, isolation of the offender ought to be the dominant aim:

Sympathy for one so young in such a situation is understandable. However, the pattern of behavior in this case is disturbing. . . . This defendant was lying in wait for his victims, armed with a knife. There were four separate deliberate attacks in a period of about six weeks. Under such circumstances the protection of the public is the paramount consideration and in our opinion the sentences are inadequate. A modification of sentence is required. ${ }^{75}$

Accordingly, the sentence was increased to eight to fifteen years. This opinion suggests the following "sentencing principle" to a trial judge: where the offender has committed repeated crimes of violence, isolation will ordinarily be the dominant aim and will require a substantial period of incarceration notwithstanding mitigating factors such as the offender's youth ${ }^{\text {70 }}$ and below-average

70. The maximum penalty for rape is thirty years. Cows. GeN. STAт. $\$$ 53-23S (1958), and for assault with intent to rape, ten years, Covs. Ges. STAт. \$ 53-239 (1958).

71. The use or possession of a weapon during the commission of a crime is an aggravating factor in all cases before the Division. See, e.g., State v. Cogswell, Conn. S.R.D., Oct. 7, 1958; State v. Montgomery, Conn. S.R.D., June 30, 1958; State v. Springer, Conn. S.R.D., Oct. 30, 1958; State v. Mílton, Conn. S.R.D., Dee. 31, 1959. The theory behind this reasoning is that those who carry weapons intend to use them.*

72. The poor physical or mental condition of the victim has been considered an agsravating circumstance. See State v. Baptista, Conn. S.R.D., M[ar. 6, 1959 (indecent assault on an "old and infirm man"); State v. Samson, Conn. S.R.D., May 3, 1960 (manslaughter of three year old was "particularly brutal considering the fact that the child was defective mentally").

73. Some observers of the Division's work were troubled by the publication of arrest records and nolles in the Division's opinions.* See, e.g., State v. Fulton, Conn. S.R.D., Feb. 16, 1959. It is strongly denied by members of the Division that arrest records and nolles are taken into account in reviewing sentence* In recent cases, reports of arrests and nolles have disappeared from Division opinions.

74. The recommendation of the State's Attorney is usually well received by Connecticut trial judges and by the Review Division.* See State v. Carpenter, Conn. S.R.D., Dec. 28, 1959; State v. Gaul, Conn. S.R.D., Aug. 21, 1958; State v. Giovanelli, Conn. S.R.D., Feb. 10, 1959.

75. State v. Doak, Conn. S.R.D., Oct. 7, 1958.

76. Age, however, is not always synonymous with favorable rehabilitative prospects. The National Probation and Parole Association suggests that the date at which criminal conduct first began may be more significant than the offender's age at the time of sentencing. Gutdes For Sentenctirg 38. 
intelligence. This principle could provide a starting point for the decision of similar cases in the future. For example, if the offender urges other mitigating factors such as absence of a prior criminal record, the trial judge might conclude that the dominant aim of isolation still requires a substantial sentence. Or, if the offender were of above-average intelligence, the fact that community condemnation now may call for a more severe punishment ${ }^{77}$ would not necessarily increase the period of detention required, for the original opinion made clear that the sentence imposed was in excess of that required to satisfy the aims of community condemnation or retribution.

The Division gave another example of its potential in a manslaughter case where the defendant, who had pleaded guilty, had been sentenced to ten to twelve years in the State Prison for Women. ${ }^{78}$ She had been drinking with her husband and had stabbed him following a quarrel over money. The Division has often conceded the importance of isolating the offender and deterring others in cases involving the taking of a human life. ${ }^{79}$ But it also felt that rehabilitation was important. The Division therefore examined the defendant's personal background in order to ascertain the quantum of punishment which would best serve both these aims. The defendant had no prior criminal record. She was born in the South in very poor economic circumstances, was shifted from relative to relative during childhood, and gave birth to a stillborn child at the age of thirteen. She had worked steadily since she was legally able to be employed. ${ }^{80}$ The State's Attorney characterized her marriage as happy with no prior evidence of violence. Apparently neither he nor the Division believed that the defendant, who had been drinking at the time, ${ }^{81}$ intended to kill hor husband. In the light of these factors, the Division concluded that the aims of deterrence and rehabilitation could adequately be served by a less severe sentence and that prolonged isolation of this offender was not necessary:

77. The Division evidences disfavor toward offenders who have had the opportunities inherent in advanced formal education. State v. Eveleigh, 21 Conn. Supp. 423, 158 A.2d 861 (Rev. Div. Super. Ct. 1958) ("cum laude graduate of an eastern college") ; State v. Pistey, Conn. S.R.D., July 30, 1958 (three years of college) ; State v. Baker, Conn. S.R.D., Oct. 20, 1959 (a lawyer who had many "opportunities").

78. State v. Hunter, Conn. S.R.D., Aug. 15, 1958. The maximum penalty for manslaughter in Connecticut is fifteen years. ConN. GeN. Stat. \& 53-13 (1958).

79. E.g., State v. Elliott, 21 Conn. Supp. 461, 159 A.2d 180 (Rev. Div. Super. Ct. 1958) ; State v. Frost, Conn. S.R.D., Oct. 17, 1958; State v. Gaul, Conn. S.R.D., Aug. 21, 1958; State v. Jones, Conn. S.R.D., July 25, 1958.

80. Although authorities in the field of sentencing regard the offender's work record as a major factor in determining the possibility of recidivism, see Glueck \& Guveck, 500 CrIminal Carefrs 281-82 (1930), the instant case is a rare example of the Division's consideration of this point. Compare Jones v. State, 330 P.2d 1055 (Okla. Crim. 1958) (defendant worked to support mother-three years for perjury reduced to two years).

81. The offender's intoxication at the time of the crime has been regarded as cither an aggravating factor or mitigating factor (as in the instant case). The Division's broadest statement on this issue holds that drunkenness at the time of the crime "in no sense diminishes the crime nor makes less serious the nature of the crime." State v. Gagliola, Conn. S.R.D., Dec. 31, 1959. 
[W] find that the minimum penalty imposed in this case is too severe. It is not appropriate because it does not fit the defendant's make-up and the nature of the crime committed by her. After the defendant has received adequate punishment, she should be a good risk to be on parole. Her past record including her steady working habits, her personality and experience indicate that with proper guidance and supervision it is unlikely that she will again commit the same type of crime. Weighing all factors in this case we conclude that the minimum sentence should be eight years. ${ }^{82}$

A trial judge could probably conclude that, as a general principle, the absence of intent to kill, ${ }^{83}$ coupled with an exemplary personal background, reduces the quantum of punishment needed to satisfy the deterrent aim and permits the likelihood of early rehabilitation to become a relevant factor.

The aims of rehabilitating the offender and of deterring other persons may' conflict, however. In that event one or the other must be selected as dominant, and the Division thas occasionally demonstrated the process of resolving such conflicts. The defendant was convicted of fourteen counts of common-law burglary and six counts of breaking and entering. He was sentenced to twelve to seventeen years in the State Prison. ${ }^{34}$ While these crimes involved no violence, "the planning and execution of the operations had the earmarks of experts. The activities of the group ${ }^{85}$ in burglarizing homes and stores were among the most extensive that authorities had . . . to consider in a long time." 80 The offender's prior record consisted of only two offenses committed while in military service, but the Division did not discuss the defendant's personal background:

The sentences imposed upon the defendant are fair, reasonable, and appropriate.... The activities of the present defendant were extraordinary in respect to the multiplicity of crimes committed and the videspread scope of them, in respect to the professional and organized character of them, and in relation to the relatively major part he played in their commission. ... The aim of punishment is not alone the rehabilitation of the offender, but equally the protection of the public against such widespread, organized, deliberate, premeditated, felonious criminal conduct.

82. State v. Hunter, Conn. S.R.D., August 15, 1958.

83. Intent is a factor frequently ruled to be aggravating by the Division. E.g., State v. Mele, Conn. S.R.D., Oct. 30, 1958; State v. Penn, Conn. S.R.D., Aug. 15, 1958; State v. Johnson, 21. Conn. Supp. 381, 158 A.2d 746 (Rev. Div. Super. Ct. 1958) (armed robber used no violence but he had a "violent intent").

84. State v. Daniels, Conn. S.R.D., Sept. 25, 1958. The maximum sentence for common law burglary is twenty years, CoNN. GEN. STAT. $\$ 53-68$ (1958); for breaking and entering, four years, Conn. GEN. STAT. \$ 53-76 (1958).

85. The Division will distinguish between co-defendants on the basis of prior record and/or degree of participation in the crime. See State v. Cogswell, Conn. S.R.D., Oct. 7, 1958; State v. Tuscano, 21 Conn. Supp. 455, 158 A.2d 598 (Rev. Div. Super. Ct. 1958); State v. Vitolo, Conn. S.R.D., Sept. 25, 1958 (the "brains of the operation").

86. Minltiple crimes cause the Division to lay emphasis upon deterrence. State v. Consiglio, Conn. S.R.D., Dec. 31, 1959; State v. Doak, Conn. S.R.D., Oct. 7, 1958; State v. Dunigan, Conn S.R.D., Dec 31, 1959. 
A substantial prison term serves the dual purpose of deterring the particular offender as well as others who may be similarly inclined. ${ }^{87}$

The implication that a long sentence was needed to deter the offender even though a shorter sentence would rehabilitate him seems anomalous. Nevertheless, the opinion can be rationalized on the ground that the shorter rehabilitative sentence frustrated the aim of deterring other potential offenders. A sentencing judge may conclude, therefore, that professional criminal conduct, ${ }^{8 *}$ indicating careful planning and culminating in a series of offenses, calls for the emphasis upon the deterrent aim by the imposition of a high minimum sentence in spite of the offender's relatively minor criminal record.

In some opinions, the Division fails to specify the relevant sentencing goals, but instead simply lists certain facts about the offender and the offense which are apparently treated as factors of aggravation or mitigation. From these factors, the reader may be able to glean the determinative sentencing aims. In one such case, ${ }^{89}$ the defendant was convicted of failure to keep a proper record of the sale of a firearm. A sentence of two to three years was imposed. ${ }^{00}$ The Division discussed the following factors: the defendant had previously been convicted of assault with intent to kill as well as numerous minor offenses; the offense in this case was a technical violation-the defendant kept a record but not on the proper form; without the defendant's knowledge the gun was later to be used in a series of murders for which the purchaser was under sentence of death; the defendant's violation in no way impeded the investigation of the murders. From these facts the Division concluded that the minimum sentence should be reduced from two years to one year. What were the relevant sentencing goals in this case? Rehabilitation was probably not determinative. If this forty-seven-year-old offender's ${ }^{21}$ background and prior record are emphasized, a one year minimum sentence might not effectuate his rehabilitation. Moreover, he was convicted of only a technical statutory violation which did not evidence the type of criminality ordinarily requiring rehabilitative incarceration. Deterrence was probably relevant in the Division's decision to reduce sentence. Surely, a minimal prison sentence would have been sufficient to induce the offender and other dealers in firearms to record their sales on the

87. State v. Daniels, Conn. S.R.D., Sept. 25, 1958.

88. "Professional criminals" are sternly dealt with by the Division. State v. Marfeo, Conn. S.R.D., Oct. 15, 1958; State v. Onorato, Conn. S.R.D., Oct. 17, 1958; State v. Rulli, Conn. S.R.D., Oct. 17, 1958; State v. Springer, Conn. S.R.D., Oct. 30, 1958; State v. J. Smith, Com. S.R.D., Oct. 2, 1958. For a definition of "professional criminal," see Michael \& Wechsler, Criminal Law and Its Administration 22-23 (1940); Model Penal Code $\$ \S 7.03(2), 7.04(2)$ (Tent. Draft No. 4, 1955).

89. State v. X. Because some of the information quoted in text is from confidential documents, the name of this case is withheld.

90. The offense is punishable by a maximum of three years in State Prison. ConN. GEN. STAT. § 29-37 (1958).

91. Before the Division, age is normally the reciprocal of rehabilitative possibility. See State v. Baker, Conn. S.R.D., Oct. 20, 1959 (52 years old); State v. Consiglio, Conn. S.R.D., Dec. 31, 1959 (42 years old). 
proper form. Indeed a fine and a suspended sentence, as recommended by the State's Attorney, would probably have served this purpose. The one-year minimum sentence might have been retained, however, to deter activity of a more general nature. The offender had been described as "one of those businessmen who operate on the fringe areas of the law ... the results of ... [whose] behavior are often far-reaching and serious to the rest of society." The result may also be explained as an expression of community condemnation. Here the Division's opinion could have given significant guidance by defining the limits of applicability of this aim. Was the Division intimating that this offender was more blameworthy because the gun he sold was later used in a murder ?"3 $^{93} \mathrm{Or}$, did the fact that he was an operator "on the fringe areas of the law" turn his technical violation into an event which merited the community's condemnation? While a trial judge might thus limit somewhat the possibly relevant sentencing aims, he could not with certainty deduce any generally applicable sentencing principles from this case.

A similar opinion dealt with the case of a police chief who had pleaded guilty to embezzling more than 6000 dollars from the local Police Benevolent Fund. ${ }^{94}$ He appealed a sentence of from two to four years, the statutory maximum for this offense being ten years. ${ }^{95}$ The Division's brief opinion noted that the defendant had readily admitted his guilt ${ }^{\circ 0}$ and that full restitution had been made.97 It weighed the offender's "many years of fine service to the community" and felt that it was "obvious that the defendant's extensive drinking contributed to the sorry state in which he found himself, financially

92. Synopsis, State v. X.

93. In reply to the State's Attorney's recommendation of a $\$ 300$ fine and a one year suspended sentence, the sentencing judge remarked:

That recommendation I cannot accept. I would sooner sec him walk out of this courtroom with a complete nolle than the let this man walk out with a three hundred dollar fine, the man who sold the guns to [the convicted murder] which resulted in the killings. ... My only regret is that I've got a three year maximum. Synopsis, State v. X.

94. State v. Cattaneo, Conn. S.R.D., Apr. 1, 1959.

95. Conn. Gen. Stat. § 53-354 (1958).

96. The defendant's confession is ordinarily praised by the Division but it is yet to be reflected in a sentence reduction. See, e.g., State v. Reid, Conn. S.R.D., June 30 , 1958; State v. Jaresko, Conn. S.R.D., Oct. 7, 1958. A failure to confess may be regarded as an aggravating factor. See State v. Colluccio, Conn. S.R.D., Sept. 11, 1958; State v. Tuscano, 21 Conn. Supp. 455, 158, A.2d 598 (Rev. Div. Super. Ct. 1958). If, in sex cases, the failure to confess forces complaining witnesses to take the stand, the offender will be persona non grata before the Division. See State v. Owens, 21 Conn. Supp. 418, 158 A.2d 867 (Rev. Div. Super. Ct. 1958). A voluntary arrest will help the defendant before the Division. See State v. Carter, 21 Conn. Supp. 426, 158 A.2d 862 (Rev. Div. Super. Ct. 1958) (second offense, narootics-ten to twelve reduced to five to ten).

97. The Division has yet to reflect the restitution of stolen property in a reduction of sentence. See State v. Rothermel, Conn. S.R.D., Oct. 15, 1958 (restitution of \$34i is "to their credit"-sentence affirmed); State v. Rulli, Conn. S.R.D., Oct. 17, 1958. Compare Glenn v. State, 72 Okla. Crim. 165, 114 P.2d 192 (1941) (restitution by surcty is a mitigating factor-sentence reduced). 
and matrimonially."98 Despite the mention of these mitigating factors, the Division affirmed the sentence imposed. Isolation and deterrence of the offender were probably not the paramount aim-he is unlikely ever again to find himself in a position of substantial trust. Secondary deterrence may have been relevant but was apparently not dominant, for the comparatively low minimun sentence was affirmed. Nor does rehabilitation of the offender seem to have been determinative; since the Division attributed the offense to the defendant's alcoholic and matrimonial difficulties, probation accompanied by professional counseling would have been a more suitable rehabilitative device than incarceration. The desire for retribution was apparently mitigated by the full restitution of the stolen funds. Community condemnation, therefore, was probably the determinative aim. In terms of the offense, a breach of trust by a high police official demanded incarceration, to reaffirm the standard of conduct demanded of persons in a position of trust. ${ }^{90}$ But since the opinion fails to discuss any of these sentencing aims, the reliability of the sentencing principle extracted is slight.

An implied resolution of two competing aims of sentencing may be strrmised from a case which involved a wife convicted of the manslaughter of her husband. ${ }^{100}$ The defendant had been indicted for first degree murder, was permitted to plead guilty to manslaughter, ${ }^{101}$ and received a sentence of from ten to twelve years. ${ }^{102}$ The Division's opinion reviewed the facts of the case and concluded that "the charge to which she pleaded guilty is a serious one and the events described herein certainly do not justify the killing of her husband." It also emphasized, however, that her husband had been a "man of poor repute." Throughout the seventeen years of their married life he had used violence upon her and had carried on adulterous relationships with other women. The sentence was reduced to five to twelve years. Because the Division felt that the crime was "induced" by the decedent's prior conduct,

98. Alcoholic tendencies are normally weighed against the defendant by the Division. State v. Eveleigh, 21 Conn. Supp. 423, 158 A.2d 861 (Rev. Div. Super. Ct. 1958). State v. King, Conn. S.R.D., Aug. 21, 1958; State v. Thorpe, Conn. S.R.D., Feb. 16, 1959. Occasionally, however, alcoholism may mitigate. See State v. Daley, Conn. S.R.D., Scpt. 25, 1958 (mitigating factor in co-defendant's sentence).

99. The betrayal of a position of trust it always an aggravating factor. See State v. Salta, 21 Conn. Supp. 477, 159 A.2d 187 (Rev. Div. Super Ct. 1958). See also Guides For Sentencing 33.

100. State v. Dinardo, Conn. S.R.D., July 22, 1959.

101. The indictment for first degree murder does not receive mention in the Division's opinion. New Haven Evening Register, June 4, 1958, p. 42, col. 5. Ordinarily those indicted for second degree murder are reminded of their luck in being allowed to plead guilty to manslaughter. See State v. Pemberton, Conn. S.R.D., Oct. 7, 1958; State v. Tardiff, Conn. S.R.D., Aug. 21, 1958. Indeed, some have been declared lucky in that they have not been indicted for second degree murder. State v. Pollard, Conn. S.R.D., Aug. 21, 1958; State v. Elliott, 21 Conn. Supp. 461, 159 A.2d 180 (Rev. Div. Super. Ct. 1958).

102. The maximum penalty for manslaughter is fifteen years in prison. Conn. Gen. STAT. \& 53-13 (1958). 
isolation or deterrence of the wife was probably not its aim. And none of the facts discussed indicate any particular need for rehabilitation. Secondary deterrence, however, may have been the objective of this sentence, to impress upon others the gravity of taking a human life. Standing alone, this might call for a severe minimum sentence. But the character of the deceased ${ }^{103}$ and his treatment of the institution of marriage may well have evoked society's sympathy for the defendant, so that community condemnation would not require a severe sanction. Thus the Division was faced with two competing goals. Because it reduced the minimum sentence to only one-third of that permitted by statute, it may be surmised that the lack of community condemnation and not the need for secondary deterrence was the dominant sentencing aim in this case. But here again the conclusion must be conjectural.

Too often, the Division's opinion lists only a minimum of factual information and does not even impliedly relate this information to a relevant sentencing objective. One such opinion, reprinted here in its entirety, states:

BY THE DIVISION. The defendant, age forty-one, pleaded guilty to the crime of incest and on October 3,1958, was sentenced to a term of not less than three nor more than seven years in state prison.

At the time of sentence the defendant had the following prior criminal record:

January 15, 1935-Hartford, Connecticut-robbery with violencecommitted to Connecticut Reformatory for five years and one day.

November 7, 1935-transferred to State Prison.

Counsel for the defendant have requested that the Adult Probation Department be ordered to make a further presentence investigation for the purpose of interviewing the defendant's wife. We can see no necessity for this, and therefore the motion is denied.

In our opinion the sentence is proper and should stand. ${ }^{104}$

This opinion could have contained an analysis of other pertinent information which was at the Division's disposal. The defendant's wife knew of the incestuous father-daughter relationship for seven months before reporting it to the police. The daughter, who was sixteen at the time of her father's arrest, admitted that her father had been "bothering her" for four years. She expressed a fear of "what might happen to her whenever the accused is

103. The character of the victim and his conduct at the time of the offense are considered. Children receive maximum protection. See State v. Tuscano, 21 Conn. Supp. 455 , 158 A.2d 598 (Rev. Div. Super. Ct. 1958) : State v. Vibert, 21 Conn. Supp. 434, 15S A.2d 596 (Rev. Div. Super. Ct. 1958). A child's complicity in a crime will not mitigate. See State v. Nasiatka, Conn. S.R.D., Dec. 28, 1959; State v. Sotire, Conn. S.R.D., July 22. 1959; cf. State v. Major, Conn. S.R.D., July 25, 1958 (statutory rape of "promiscuous" girl). In sex cases involving adults, a lack of resistance or a display of friendliness on the part of the victim may mitigate. See State v. Guiles, 22 Conn. Supp. 42, 159 A.2d 190 (Rev. Div. Super. Ct. 1959) (rape, eight to twelve reduced to five to twelve).

104. State v. Y. The name of this case is withheld because some of the material which follows is taken from the Symopsis and is confidential.

Incest is punishable by a maximum of ten years in prison. Cons. Genr. StAT. $\$$ 53-223 (1958). 
at liberty." A psychiatric diagnosis of the defendant described his condition as "sexual delinquency in a passive-dependent, inadequate personality." The state recommended a sentence of one to eight years and defense counsel urged a suspended sentence. At the time of sentencing, the trial judge, who had learned that the daughter would graduate from high school in 1960 , set a three-year minimum because "I want to get beyond 1960 if I can." In addition, he recognized that rehabilitation might require a substantial period of parole under supervision, as evidenced by his desire for a "reasomably long stretch between the minimum and the maximum." Had the Division's opinion included this additional information, it would have at least implied that isolation of the offender and rehabilitation are the relevant aims in this type of case. As it stands, the decision proffers no guidelines for future decisions.

Even less helpful was the opinion in a case involving a first-offender who had pleaded guilty to indecent assault. ${ }^{105}$ The statutory maximum sentence for this offense is ten years $;^{106}$ the defendant received one to three. Other than a statement that the defendant had no prior criminal record the opinion states only the facts of the crime: the defendant had had "unnatural sex relations with a fourteen-year-old mentally retarded boy on the average of once or twice a week. On each occasion the defendant gave the boy fifty cents." The opinion then concludes: "We can discover nothing in the record of this case to warrant any change in sentence. In our opinion the sentence is proper and should stand." 107 Consider the position of a trial judge faced with a sentencing clecision in a similar case. How will this opinion help him? Is the fact that the defendant "gave the boy fifty cents" of any significance? Is a distinction to be drawn between those who violently assault their victims and those who bribe them? Does the victim's mentally-retarded condition enter into the decision ? ${ }^{108}$ Was the youth of the victim an aggravating factor ${ }^{300}$ More important, the opinion does not indicate what goals the sentence was flesigned to achieve. Was the sentence intended to facilitate this offender's rehabilitation? If so, did

105. State v. Sotire, Conn. S.R.D., July 22, 1959.

106. Conn. Gen. Stat. § 53-217 (1958).

107. State v. Sotire, supra note 105.

108. Cf. Conn. Gen. Stat. § 53-225 (1958) (carnal knowledge of or by a feebleminded person punishable by maximum of three years in prison).

109. Compare the Division's philosophy in dealing with sex crimes against children, as expressed in State v. Vibert, 21 Conn. Supp. 434, 158 A.2d 596 (Rev. Div. Super. Ct. 1958):

Furthermore, it should be noted that in crimes involving injury or risk of injury to children, relatively more severe sentences may be justified where the circumstances reasonably warrant it, for several reasons. There is need for protecting the young from their own indiscretions of this nature, who are not infrequently led into them by the enticements held out, or decoys contrived, for the purpose by an offender. Furthermore, in this type of offense, convictions may not follow the earlier instances of the commission of them, and difficulty of proof is not infrequently encountered by prosecuting authorities in presenting a violation in court. 
the record contain evidence, such as a psychiatric study, indicating that the designated period will be long enough to accomplish this purpose?110 On the other hand, was the sentence intended to isolate this offender from society ?111 $^{111}$ If so, the Division should have articulated its reasons for believing that the one-year minimum was a sufficient deterrent. Or, perhaps the Division meant to imply that community condemnation and retribution were the dominant aims. ${ }^{112}$ Assuming that this is true, the reader is still unable to determine whether deterrence and rehabilitation have been relegated to a secondary position merely because of the peculiar facts of this case or whether community condemnation and retribution are deemed the dominant aims in all cases involving "unnatural sex relations." The Division's failure, in most of its opinions, to articulate the answers to questions such as these creates a major limitation on its value as a forum for the development of uniform sentencing principles. ${ }^{113}$

\section{Response to the Sentence Revicw Division}

As a result of the few sentence modifications made and the Division's reluctance to articulate sentencing policies, the Division has not aroused the interest of bench, bar, and public. Originally, the legislature provided for publication of the Division's opinions in the Connecticut Supplement, presumably making them available to all lawyers and judges in the state. ${ }^{11}$ But the Connecticut judges interviewed have stated that, except when called upon to serve on the Review Division, they read only those opinions reviewing cases in which they were the trial judge.* The bench, in fact, tends to view

110. The rehabilitation of sex offenders is regarded by the Division as a very difficult task. State v. Roberts, Conn. S.R.D., Mar. 6, 1959 ("quite doubtful if this defendant's behavior can ever be corrected") ; State v. Mason, Conn. S.R.D., June 30, 1958 ("the not infrequent recidivistic character of such offenders").

111. Isolation is frequently articulated as the primary aim in sex cases. State v. Bentedict, Conn. S.R.D., Oct. 7, 1958; State v. Butler, Conn. S.R.D., June 30, 195S; State v. LeBlanc, Conn. S.R.D., Sept. 11, 1958; State v. Owens, 21 Conn. Supp. 418, 158 A.2d 867 (Rev. Div. Super. Ct. 1958).

112. See State v. L. G. Daniels, Conn. S.R.D., Oct. 17, 1958 (incest-"vicious and despicable"); State v. Pratt, Conn. S.R.D., Oct. 7, 1958 (incest-"revolting, vicious, and inherently immoral"); State v. Mille, Conn S.R.D., Feb. 10, 1959 (rape-"inherent wrong") ; State v. Minnson, Conn. S.R.D., Oct. 22, 1959 (indecent assault-"repulsive, cruel, sadistic and perverted acts").

113. It should be noted that approximately one-fourth of the appeals to the Review Division came from offenders sentenced under Connecticut's narcotics laws which, until 1959 , required a minimum five-year sentence for the illegal use, possession, or sale of narcotics. Conn. Gen. Stat. $\$ 2103$ (d) (Supp. 1955). Naturally all appeals against minimum sentence were futile, and most were briefly disposed of. See, e.g., State v. Hodge, Conn. S.R.D., Oct. 17, 1958. Although the mandatory minimum for addicts has been abolished, Conn. Gen. Stat. \$ 19-265a, (Supp. 1959), it remains applicable to sellers, Cosis. Ger: STAT. § 19-265 (Supp. 1959).

114. Conn. Gen. Stat. § 51-196 (1958). 
the Division not as an affirmative policy-oreating body, but only as a resraint on palpably unreasonable sentencing decisions. ${ }^{115}$ The Division has occasionally indicated that the sentence imposed by the trial judge will be affirmed so long as it meets a "reasonable judge" test, ${ }^{116}$ a statement of little assistance to a trial judge seeking a positive statement of principles for future application. To compound this problem, the 1959 Session of the Connecticut General Assembly has removed the mandatory publication requirement. Instead, it instructed the Recorder of Judicial Decisions to "select . . . for publication such decisions as he deems will be useful as precedents or will serve the public interest."117 Now, even those opinions which should be of interest to the judiciary may be unavailable.

The Connecticut bar shares the judiciary's disinterest in the work of the Division. Prosecutors and defense counsel alike have stated that they did not read the opinions even when all were published.* The appearances of defense counsel before the Division have been relatively few.118 They feel that the practical value of such appearances is minimal, since the vast majority of opinions affirm the sentence imposed.* State's Attorneys tend to view their required appearances before the Division as an unnecessary burden.* Like defense counsel, they feel that the Division's only function is to apply the "reasonable judge" test and that the use of presentence reports by trial judges 11" reduces the likelihood that the Division will find many palpably unreasonable sentences.* Thus it is not uncommon to find State's Attorneys offering little or no comment at the review hearing.* This disinterested attitude has increased the difficulty of realizing the patentialities of the Review Division. Considering the present quality of Division opinions, greater scrutiny and criticism by the bar of such sentencing principles as are proposed would contribute substantially to the improvement of future opinions and, ultimately, to the improvement of the sentencing process itself.

Since criminal sentencing and, indeed, the criminal process as a whole are oriented toward effectuating community objectives, informed public criticism

115. This opinion is shared by the bar and is manifested in the repeated suggestion that a more active use of the pardoning power would obviate the need for a Sentence Review Division,*

116. See, e.g., State v. Major, Conn. S.R.D., June 30, 1958 ("the defendant . . . has not been dealt with in an improper or unreasonable manner"). Examples of deference to the trial judge due to his view of demeanor evidence also suggest this criterion. Sce notes $65-66$ supra. Hall suggests that a sentence must be substantially erroneous to merit modification. Hall, 776 n.74.

117. Conn. Gen. Stat. § 51-196 (Supp. 1959).

118. Only 55 of the 256 appellants whose cases have been adjudicated by the Review Division have been represented by counsel. Counsel were present at 3 of the 15 sentence reductions, at only 1 of the 7 increases. Tabulation from Sentence Review Division files.

119. Presentence reports are mandatory for all first offenders (except first degrce murderers) and for those whose most recent prior conviction is more than three years before the instant crime. Conn. Gen. Stax. \$ 54-109 (Supp. 1959). 
is also essential. ${ }^{120}$ For example, if the Division's opinions, stressing the aim of rehabilitation, revealed that certain types of offenders were being committed to state prison only because better rehabilitative facilities did not exist, ${ }^{121}$ the public might urge the legislature to provide the needed facilities. Similarly, if the public felt that the Division was not sufficiently emphasizing the deterrent aim in certain types of offenses, it might prevail upon its representatives to enact mandatory minimum penalties for these offenses. ${ }^{122}$ Before it can suggest policy decisions, however, the public must be informed of the standards proposed by the Division. The press is the logical source of such informatiun. It should realize, therefore, that not only the results of a particular case must be reported, but also the sentencing goals which formed the basis of the Division's opinion.

To date, the most serious drawback to the Division's effectiveness has been the idea that it's primary function is to prevent "horrible sentencing examples." By seldom attempting to supply generally applicable sentencing criteria, the Division has overlooked its most significant potentialities and has lost the interest of other participants and decision-makers of the criminal process. Unless it assumes the role of an affirmative policy-maker, ${ }^{123}$ ad hoc, instinctive decisions will continue to impede development in the field of sentencing.

120. For a consideration of public review of earlier phases of the criminal process, sce generally Goldstein, Police Discretion Not To Inwoke the Criminal Proccss: Lou-Visibility Decisions in the Adninistration of Justce, 69 Y ALE L.J. 543 (1960).

121. See State v. DeMrichael, Conn. S.R.D., Aug. 1, 1958 ("the courts had no other place to send [sex offenders] but to state prison") ; State v. Veysey, Conn. S.R.D., July 30, 1958 (sex offender sent to prison "in the absence of more effective remedial treatment and facilities"); State v. O'Connor, 21 Conn. Supp. 474, 159 A.2d 185 (Rev. Div. Super. C. 1958) (arsonist sent to prison, given "the benefit of such correctional and remodial facilities as were available to the court"). See also the statement of a trial judge on sentencing day:

What is the court supposed to do, indulge in some clinical research? . . . [I]f we had an institution or had means by which this sort of thing could be observed and treated without placing an individual like this behind bars, that is where he belongs, but I don't think under what I see here that he should be permitted at large simply because I have a few statements here which seem to indicate further treatment may do some good.

Synopsis, State v. Sotire, Conn. S.R.D., July 22, 1959.

122. In a reverse situation, the Review Division, operating under a statute which imposed a five year mandatory minimum sentence for both users and sellers of narcotios, attempted to distinguish between classes of offenders by varying the maximum penalty Compare State v. Perez, 21 Conn. Supp. 421, 158 A.2d 748 (Rev. Div. Super. Ct. 1958) (sort-time user; five to ten reduced to five to seven), with State v. Heyward, Conn. S.R.D., Oct. 17, 1958 (seller, five to seven increased to five to ten). These opinions may have influenced the abolition of the mandatory minimum for users in 1959, Cows. GEr. Star. $\S \S 19-265,19-265 a$ (Supp. 1959).

123. One immediate improvement in the Division's opinions can be made by increasing the number of cross-citations which appear in the opinions. To date, the Division has confined itself almost exclusively to citing cases which articulate the state's narcotics policy and cases which hold that the panel cannot retry guilt. The Division has said that 
it compares cases. State v. Howard, Conn. S.R.D., May 1, 1958. It should begin to cite these cases.

Interchange of information among the decision-makers in this area might also be facilitated by adoption of a plan paralleling 28 U.S.C. $\S 334$ (1958). Under this plan the Chief Justice of the Supreme Court of Errors could convene institutes for the purpose of discussing "objectives, policies, standards, and criteria for sentencing." While judges would form the nucleus of these institutes, they could invite, at their discretion, penologists, members of the bar, the legislature, and behavioral scientists. For the comments of federal judges on such a plan, see Federal Sentencing Procedures 25-42. The first institute conducted under the federal act was a success. Sharp, The Pilot Institute on Sentencing, 23 FEd. Prob. No. 4, p. 9 (Dec. 1959). 